\title{
Årsberetning
}

\section{De nordiske kriminalistforeninger 2011}

\section{Kriminalistforeningen i Danmark}

Foreningens formand er direktør William Rentzmann. Sekretær og kasserer er advokat Jakob Lund Poulsen, som blev valgt ind i bestyrelsen ved generalforsamlingen den 3. februar 2011, i stedet for advokat Bjørn Høberg-Petersen der ønskede at forlalde bestyrelsen. Bestyrelsen bestod i 2011 endvidere af professor Flemming Balvig, overlæge Peter Kramp, forskningschef Britta Kyvsgaard, professor Gorm Toftegaard Nielsen, rigsadvokat Jørgen Steen Sørensen, højesteretsdommer Poul Dahl Jensen, arrestinspektør Jens Tolstrup, fuldmægtig Susanne Clausen, professor Thomas Elholm, vicepolitidirektør Arne Vedsted Gram, retspræsident Birgitte Holmberg-Petersen, og departementschef Anne Kristine Axelsson som midlertidigt indtrådte i bestyrelsen i forbindelse med, at hun blev udnævnt som ny departementschef efter Michael Lunn.

Generalforsamling i foreningen fandt sted den 3. februar 2011. Efter generalforsamlingen holdt sociolog Christian Klement og politiinspektør i NEC, Kim Kliver, oplæg om henholdsvis »Bander og rockere. Hvilke risikofaktorer karakteriserer dem? Adskiller de sig fra andre kriminelle? " og »Bandekonflikterne -dens aspekter, indsatsen og resultaterne«.

Dansk Kriminologisk Selskab, der er et datterselskab til Dansk Kriminalistforening, arrangerede fem møder i 2011. Den 21. marts indledte chefjurist i CEPOS, Jacob Mchangama om »Kriminalisering af ytringer (racisme, blasfemi etc.)«. Den 12. april indledte seniorforsker ved Institut for Menneskerettigheder, Peter Scharff Smith, om »Børn af fængslede«. Den 4. oktober indledte sociolog Christian Klement og fuldmægtig Tanja Tambour Jørgensen fra Justitsministeriets Forskningskontor om »Nye evalueringer af alternativer til frihedsstraf (fodlænke og samfundstjeneste) « og den 22. november indledte forstander på den sikrede ungdomsinstitution Egely, Flemming Pommer, og cand.psyk. Stine Rønholt om »Screening af unge for psykiske problemer«.

Den 31. oktober afholdte Selskabets fynske afdeling i samarbejde med Juridisk Institut, Syddansk Universitet, arrangement med oplæg ved overlæge Peter Kramp »Samarbejde mellem kriminalforsorgen i frihed og psykiatrien - samt lidt om behandlingen af retspsykiatriske patienter«.

Ved årets udgang havde Dansk Kriminalistforening 365 medlemmer. 
Kriminalistforeningen i Sverige

Vid Svenska Kriminalistföreningens årsmöte den 3 maj 2011 omvaldes föreningens ordförande Jan Andersson och styrelseledamöterna Gudrun Antemar, Agneta Bäcklund, Malena Carlstedt (sekreterare), Sten Heckscher, Tomas Rothpfeffer, Magnus Ulväng, Jerzy Sarnecki, Bengt Svenson och Fredrik Wersäll,. Till nya styrelseledamöter valdes rättssakkunniga Jenny Holmqvist(kassör) och professorn Martin Grann. Ämnesrådet Patrik Örnsved och jur. kand. Anna Kers valdes som revisorer och ämnesrådet Göran Nilsson till revisorssuppleant. Styrelsen har sammanträtt 4 gånger under året.

Under året fyllde föreningen 100 år. Med anledning av det anordnade föreningen ett eftermiddagsseminarium på temat Kriminalpolitik under 100 år och därefter en festmiddag. Bland talarna återfanns bland annat den tidigare svenska justitieministern Laila Freivalds och forskningschefen vid det danska justitieministeriet Britta Kyvsgaard. Seminariet innehöll också en panel som diskuterade de kriminalpolitiska utmaningarna i framtiden. Utöver 100-års jubileet anordnade föreningen tre pubkvällar. På den första puben presenterade professor Dennis Töllborg sin syn på internutredningsverksamheten inom polisen. På den andra puben berättade författarna till boken Svenska maffia, Lasse Wierup och Matti Larsson, om sitt arbete med boken. Temat för den tredje puben var Straffmätning i narkotikamål - Håller HD på att vända upp och ner på tillvaron? Under puben diskuterade rådmannen Lena Egelin och vice överåklagaren Astrid Eklund samt många närvarande medlemmar under ledning av hovrättspresidenten Fredrik Wersäll. I samband med föreningens årsmöte arrangerades vidare en debatt på temat Vilken kunskap behöver kriminalpolitiken? Om vad? Varifrån? Och bryr man sig? I debatten, som leddes av den tidigare ordföranden i Högsta förvaltningsdomstolen Sten Heckscher, deltog personer från både myndigheter, departement och forskarsamhället.

Vid årets utgång hade föreningen sammanlagt 191 medlemmar.

Kriminalistforeningen i Island - Sakfrceðifélag Íslands

Foreningens formand er professor Ragnheiður Bragadóttir.

I 2011 afholdt foreningen ét møde.

Den 16. november arrangerede foreningen et møde i samarbejde med Det Juridiske Institut, Islands Universitet og Orator, Jurastuderendes Forening. På mødet holdt professor Lars Bo Langsted en forelæsning med navnet: Bribery and the Like - in a Nordic context with an outlook to the new British legislation. Ordstyrer var Ragnheiður Bragadóttir. Til stede var 22 gæster 
Kriminalistforeningen i Finland - Suomen Kriminalistiyhdistys

Föreningens styrelse har under redogörelseåret haft följande sammansättning; ordförande: docent Jussi Matikkala, viceordförande: generaldirektör Esa Vesterbacka, sekreterare och kassör: jur. kand. Dan Helenius. Styrelsens övriga medlemmar bestod av följande personer: överläkare Irma Kotilainen, vicechef Sanna Heikinheimo, specialsakkunnig Henrik Linderborg, institutionschef Tapio LappiSeppälä, hovrättsråd Timo Vuojolahti, häradsåklagare Yrjö Reenilä, doktorand Merita Huomo-Kettunen och jur. kand. Mikko Virkamäki. Styrelsen sammanträdde två gånger år 2011; den 5 maj och den 14 november.

Professor Inkeri Anttila är hedersmedlem i föreningen.

Föreningen höll den 3 mars 2011 ett diskussionstillfälle tillsammans med ämnesföreningarna Codex r.f. och Pykälä r.y. Temat för diskussionen var »Immigration, kriminalitet och kriminalpolitik«. Diskussionspanelen bestod av jurist, riksdagsledamotskandidat Husein Muhammed, forskare Jenni Niemi, statssekreterare Antti Pelttari samt migrations- och europaminister Astrid Thors.

Föreningens årsmöte hölls den 5 maj 2011. Temat för mötet var »Farlighetsbedömning av personer skyldiga till grova brott«. Inledningsanföranden till diskussionen hölls av professor Hannu Lauerma samt hovrättsråden Pertti Lattunen och Olli Mäkinen.

Föreningens höstmöte hölls den 14 november 2011. Temat för mötet var »Polisens täckoperationsverksamhet«. Inledningsanföranden till diskussionen hölls av biträdande chef Tero Kurenmaa (Centralkriminalpolisen) och äldre justitieombudsmannasekreterare Juha Haapamäki.

Vid årets slut hade föreningen 252 medlemmar.

Kriminalistforeningen $i$ Norge

Arsmøtet 2011

Årsmøtet 2011 ble holdt 16. februar 2011 på Litteraturhuset i Oslo, møterom Nedmja.

Årsberetning og regnskap for 2010 ble godkjent. Regnskapsoppsett ble levert påfølgende styremøte.

I samsvar med innstilling fra valgkomiteen ble følgende styre valgt:

Førstestatsadvokat Runar Torgersen, Riksadvokatembetet (leder)

Juridisk rådgiver ved Spesialenheten for politisaker Guro Kleppe (nestleder)

Post doc. Jørn R.T. Jacobsen, Juridisk fakultet, Universitetet i Bergen (styremedlem)

Avdelingsdirektør, nå ass. riksadvokat, Knut Erik Sæther, Lovavdelingen, Justisdepartementet (styremedlem) 
Advokat Arne Gunnar Aas, Advokatfirmaet Hjort (styremedlem)

Forsker Jane Dullum, Institutt for kriminologi og rettssosiologi, Universitetet i Oslo (vara)

Direktør Tor Langbach, Domstoladministrasjonen (vara)

Revisor:

Advokat Roar Østby

Valgkomiteen:

Lagdommer Anne Samuelson, Borgarting lagmannsrett

Professor Ulf Stridbeck, Juridisk fakultet, Universitetet i Oslo

Post doc. Ragna Aarli, Juridisk fakultet, Universitetet i Bergen

\section{Styrets sekretcer og medlemsregisteret}

De siste årene har det vært lite kontinuitet i sekretærfunksjonen. Dommerfullmektig Tandberg, Oslo tingrett, fra 1. oktober 2011 seniorrådgiver i Justisdepartementet, har vært foreningens sekretær i 2011. Foreningen har benyttet tjenesten Medlemsservice.no med vekslende hell. Det er fortsatt et problem at det er svært tidkrevende å føre medlemsregisteret, og at systemene fortsatt er slik at det er store muligheter for menneskelige feil. En del medlemmer melder heller ikke fra om adresseforandring, noe som skaper problemer, $i$ tillegg til at tidsskriftet sendes fra Danmark, noe som også er en utfordring. Registeret drives for øvrig på frivillig basis. Styret registrerer at arbeidet med å få registeret à jour fortsatt må gis høy prioritet.

\section{Debattmøter}

Foreningen har arrangert tre debattmøter.

Tema for møtet etter årsmøtet 16. februar 2011 var »Straffenivået i Norge«. Innledere var forsker Leif Petter Olaussen, Institutt for kriminologi og rettssosiologi, Universitetet i Oslo,

Hans Frode Kielland Asmyhr (FrP), Justiskomiteen og advokat Mette Yvonne Larsen, Advokatfirmaet Stabell \& Co. Møtet fant sted i Litteraturhuset, møterom Nedmja.

Den 12. april 2011 var $»$ Varetektsfengsling « tema for debattmøtet. Innledere var stipendiat og advokat Thomas Horn, Institutt for offentlig rett, $\mathrm{UiO}$, advokat Frode Sulland, Advokatfirmaet Hestenes og Dramer \& Co samt statsadvokat Stein Vale, Oslo statsadvokatembeter. Møtet ble holdt på Juridisk fakultet, Universitetet i Oslo.

Den 7. desember 2011 ble det arrangert debattmøte om »Avvik i strafferetten: Hvordan reagere mot de syke og/eller onde?«. Innledere var psykiater Randi Ro- 
senqvist og professor Aslak Syse. Møtet fant sted i Litteraturhuset i Oslo, møterom Kverneland.

Styrets aktiviteter

Det har - i tillegg til årsmøtet - vært avholdt tre styremøter i 2011 (17. mars, 27. oktober og 7. desember). Styrets leder har hatt to møter med sekretæren. Ellers har synspunkter og ideer blitt utvekslet per e-post.

\section{Medlemmer}

Per august 2011 hadde foreningen 209 medlemmer. 